\title{
Seasonal variation in reproductive activity and biochemical composition of flat oyster (Ostrea edulis) in the Homa Lagoon, Izmir Bay, Turkey
}

\author{
Sefa Acarli ${ }^{1}$, Aynur Lök ${ }^{2}$, Ali Kirtik ${ }^{2}$, Deniz Acarli ${ }^{3}$, Serpil Serdar ${ }^{2}$, Aysun Kucukdermenci ${ }^{2}$, \\ Selcuk Yigitkurt ${ }^{2}$, Harun Yildiz ${ }^{1}$, Asiye Nur Saltan ${ }^{1}$ \\ ${ }^{1}$ Canakkale Onsekiz Mart University, Faculty of Marine Sciences and Technology, Terzioglu Campus 17100 Canakkale, \\ Turkey.E-mail: sefaacarli@comu.edu.tr \\ ${ }^{2}$ Ege University, Fisheries Faculty, Department of Aquaculture, Bornova, 35100, Izmir, Turkey. \\ ${ }^{3}$ Canakkale Onsekiz Mart University, Gökceada School of Applied Sciences, Department of Fisheries Technology, \\ 17760 Canakkale, Turkey
}

\begin{abstract}
Summary: The reproductive cycle of the flat oyster, Ostrea edulis Linnaeus, 1758, in Homa Lagoon, Izmir Bay, Turkey was examined from August 2008 to July 2009. Gonad samples were analysed histologically in order to determine the sex ratio and gonad development stage. Overall, the sex ratio was recorded as $2.2 \%$ female, $42.6 \%$ male, $37 \%$ hermaphrodite and $17.9 \%$ inactive. Glycogen content showed considerable variations between August and February, but decreased gradually thereafter. However, glycogen did not directly affect the reproductive cycle. Total lipid content was positively correlated with temperature and inversely correlated with salinity. In addition, this parameter was influenced by the reproductive activity, which is correlated with the fluctuation of the condition index and gonad index $(\mathrm{P}<0.05)$. However, the relationship between the protein index and the gonad index was negative $(\mathrm{P}<0.05)$. The results of this study showed that protein was the major energy resource. The condition index varied between $2.69 \pm 0.91$ (February) and 12.29 \pm 1.45 (April) during the year. With respect to meat yield, oyster quality changed from "fine" to "special", except in December and February.
\end{abstract}

Keywords: flat oyster; Ostrea edulis; reproductive cycle; biochemical composition; Aegean Sea; Homa Lagoon.

Variación estacional de la actividad reproductiva y de la composición bioquímica de ostra plana (Ostrea edulis) en Homa Lagoon, bahía de Izmir, Turquía

Resumen: El ciclo reproductivo de la ostra plana, Ostrea edulis Linnaeus, 1758, en Homa Lagoon, Bahía de Izmir, Turquía, fue examinado entre agosto de 2008 y julio de 2009. Las gónadas se analizaron histológicamente para determinar la proporción de sexos y su estado de desarrollo. La proporción de sexos encontrada fue $2.2 \%$ hembras, $42.6 \%$ machos, $37 \%$ hermafroditas y $17.9 \%$ inactivos. El contenido de glucógeno mostró considerables variaciones entre agosto y febrero, pero después de estos meses se produjo un aumento gradual. Sin embargo el glucógeno no afectó directamente el ciclo reproductivo. El contenido total de lípidos se correlacionó positivamente con la temperatura e inversamente con la salinidad. Además, este parámetro estuvo influenciado por la actividad reproductiva, que se correlaciona con la fluctuación del índice de condición y del índice gonadal $(\mathrm{P}<0,05)$. Sin embargo la relación entre el índice de proteína y el índice gonadal fue negativa $(\mathrm{P}<0,05)$. Los resultados de este estudio mostraron que la proteína era la principal fuente de energía. El índice de condición varió entre $2.69 \pm 0.91$ (febrero) y $12.29 \pm 1.45$ (abril) durante el año. En lo que respecta a la producción de carne, la calidad de las ostras pasó de "fine" to "special", excepto en diciembre y febrero.

Palabras clave: ostra plana; Ostrea edulis; ciclo reproductivo; composición bioquímica; mar Egeo; Homa Lagoon.

Citation/Como citar este artículo: Acarli S., Lök A., Kirtik A., Acarli D., Serdar S., Kucukdermenci A., Yigitkurt S., Yildiz H., Nur Saltan A. 2015. Seasonal variation in reproductive activity and biochemical composition of flat oyster (Ostrea edulis, Linnaeus 1758) in the Homa Lagoon, Izmir Bay, Turkey. Sci. Mar. 79(4): 487-495. doi: http://dx.doi.org/10.3989/ scimar.04202.16A

Editor: M.B. Gaspar.

Received: January 7, 2015. Accepted: July 22, 2015. Published: October 16, 2015.

Copyright: (c) 2015 CSIC. This is an open-access article distributed under the Creative Commons Attribution-Non Commercial Lisence (by-nc) Spain 3.0. 


\section{INTRODUCTION}

Oysters are the most common of all bivalves and they have been known as edible and as a delicacy for centuries. World oyster production was estimated at around 4.6 million metric tons in 2010 with a value of $\$ 3.7$ billion (FAO 2012). Shellfish cultivation is not a common practice in Turkey and only one species (Mytilus gallopravincialis) is farmed. Oysters are traditionally harvested from wild stocks for human consumption and for export (Kumlu and Lok 2007). Turkey has an enormous potential for aquaculture development due to its geo-formations, with numerous sheltered bays and estuaries and the occurrence of important economic bivalve species such as the European flat oyster Ostrea edulis (Fischer et al. 1987) and the Pacific oyster Crassostrea gigas (Doğan et al. 2005).

Homa Lagoon is a suitable lagoon for oyster aquaculture. The tidal effects and the availability of food make this lagoon one of the ten most productive lagoons in the Aegean Sea. It has large areas of salt wetlands, with a fishing area of 1800 ha whose natural population includes important commercial bivalves such as $O$. edulis, Ruditapes decussatus and Cerastoderma glaucum.

Knowledge of the reproductive cycle of $O$. edulis provides essential information for aquaculture production. In addition, knowledge of meat yield (MY) and biochemical composition will be important for marketing. It is known that the reproductive cycle, MY, condition index (CI) and biochemical composition of bivalves depends essentially on water temperature (Chávez-Villalba et al. 2003, Wilson et al. 2005, Lok and Acarli 2006) and the quantity and quality of food in the water column (Abad et al. 1995, Y1ldiz et al. 2013). A significant relationship exists especially between the reproductive cycle, the CI and biochemical composition (Berthelin et al. 2000, Yan et al. 2010, Çelik et al. 2015). Biochemical components are used for growth and as energy reserves for reproductive activity. For gametogenesis the energy is generally stored in the form of glycogen, but when food is abundant, lipids and proteins may also serve as an energy source. The particular importance of these substrates can vary among bivalve species and among populations of the same species who have different strategies for energy storage and utilization (Pogoda et al. 2013, Matias et al. 2013).

There are no studies on the reproductive cycle and biochemical composition of the flat oyster in Homa Lagoon. Therefore, the aim of this study was to determine the spawning period, MY, CI and biochemical composition of this species in Homa Lagoon.

\section{MATERIALS AND METHODS}

\section{Sample collection}

In May 2008, oyster samples (360 individuals) larger than $50 \mathrm{~mm}$ were collected in Gerence Bay $\left(38^{\circ} 25^{\prime} \mathrm{N} ; 2^{\circ} 30^{\prime} \mathrm{E}\right)$, Aegean Sea, at $1-5 \mathrm{~m}$ depth by scuba diving and the samples were transferred to Homa Lagoon (38`31'30'N; 026 50'50’E), Aegean Sea. The individuals were placed in mesh bags $(20 \mathrm{~mm}$ mesh size) that were hung on a longline culture system on the surface, which was set up in a canal (1.5 m maximum depth) between the lagoon and the sea area (Fig. 1). Thirty adult oysters were randomly taken monthly

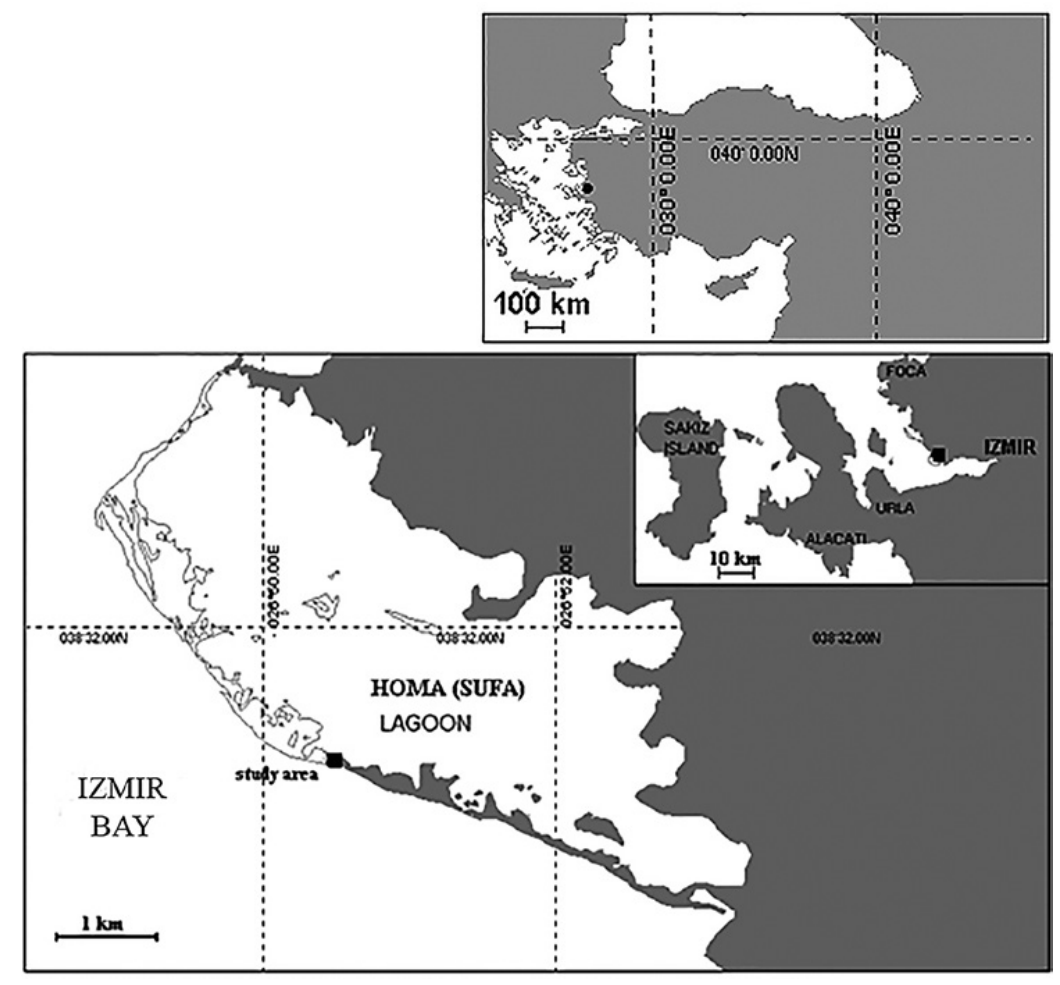

Fig. 1. - Location of the study area (full square) in Homa Lagoon, Izmir Bay, Turkey. 
from August 2008 to July 2009. During each sampling, oysters were cleaned of fouling organisms and weighed to the nearest $0.01 \mathrm{~g}$ using an electronic scale.

\section{Environmental parameters}

Hydrographical parameters such as temperature, salinity, chlorophyll $a$, particulate organic matter (POM) and particulate inorganic matter (PIM) were measured during the study. Water temperature was monitored with a temperature recorder (Star-Oddi) at six hour intervals. Salinity was measured with a light refractometer $( \pm 1 \%$ ) . Chlorophyll $a$, POM, PIM and total particulate matter were determined according to the methods of Strickland and Parson (1972). All of the measurements for determining environmental parameters, except temperature, were taken from the water surface at intervals of two weeks, and twice on each day.

\section{Meat yield and condition index}

Thirty specimens were processed monthly for analysis of the CI and MY. The MY, or AFNOR quality index, of oysters was calculated following the method of Crosby and Gale (1990):

$$
\mathrm{MY}=[\text { wet meat weight }(\mathrm{g}) / \text { total weight }(\mathrm{g})] \times 100
$$

An index between 6.5 and 9 corresponds to "fine" oysters and greater than 9 to "spéciale" oysters (Soletchnik et al. 2001). The CI was calculated according to Walne and Mann (1975):

$$
\mathrm{CI}=[\text { dry meat weight }(\mathrm{g}) / \text { dry shell weight }(\mathrm{g})] \times 100
$$

\section{Biochemical analysis}

Thirty individuals for each month were freezedried and crushed for biochemical analysis, and the samples were analysed in triplicate. Protein content (\%) was determined, according to Lowry et al. (1951), after extraction with sodium hydroxide. Total lipid (\%) was extracted with chloroform-methanol (Bligh et al. 1959). Glucide (\%) and glycogen content (\%) (precipitated with absolute ethanol) were analysed using the method of phenol-sulfuric acid, according to Dubois et al. (1956).

\section{Histology}

In order to observe the gonadal development, gonad tissue of 30 individuals for each month was fixed in Davidson solution. Samples were preserved in $10 \%$ formalin solution. The tissues from each sample were dehydrated and prepared for paraffin embedding. Embedded tissues of $4 \mu \mathrm{m}$ thickness were sectioned. Sections were mounted on glass slides and stained with a solution of haematoxylin and eosin. Each histological section of gonadal tissue was observed in detail under a microscope (BX51 4x, 10×, 20×, 40×) to assess sex and to categorized the stage of gametogenesis, which was identified according to the descriptions given by Siddiqui and Ahmed (2002); the stages are classified as inactive, early developing, developing, ripe, partly spawned and fully spawned.

\section{Gonad index}

A gonad index (GI) was calculated according to Soria et al. (2002) as follows:

$\mathrm{GI}=($ sum of individuals $*$ category $) /$ total individuals

For each stage a numeric ranking (category) was assigned as follows:

- inactive (S0): 1

- early developing (S1): 2

- developing (S2): 2

- ripe (S3): 3

- partly spawning (S4): 3

- fully spawning (S5): 1

\section{Data analysis}

Percentage data was arcsine transformed before statistical treatment. Sex ratio was analysed using chi-square $\left(\chi^{2}\right)$. The data distribution was tested using the Kolmogorov-Smirnov test to determine normality. Pearson's correlation analysis was applied to describe the relationship between environmental factors (temperature, salinity, POM, PIM and chlorophyll $a$ ), MY, CI, GI and biochemical composition. Data were analysed and statistical analyses were carried out using the SPSS 13.0 software for Windows.

\section{RESULTS}

\section{Environmental parameters}

The mean monthly variations in sea water temperature, salinity, chlorophyll $a$, POM and PIM values for the Homa Lagoon for each month are given in Figure 2. Temperature showed a clear seasonal pattern with maximum values in August of $26.3 \pm 1.54^{\circ} \mathrm{C}$ and minimum values in January of $9.8 \pm 3.15^{\circ} \mathrm{C}$. The salinity ranged between $36.2 \pm 1.1$ and $44.92 \pm 0.92$. Chlorophyll $a$ was variable throughout the year with a concentration ranging from $9.04 \pm 5.36 \mu \mathrm{g} \mathrm{L}^{-1}$ in October to $1.9 \pm 1.14 \mu \mathrm{g}$ $\mathrm{L}^{-1}$ in June. A strong correlation was observed between PIM and POM $(\mathrm{P}<0.01)$. Low values of PIM and POM were recorded as $4.85 \pm 1.74$ and $2.12 \pm 1.41 \mathrm{mg} \mathrm{L}^{-1}$ in March, respectively. Two peaks of PIM and POM were determined as $113 \pm 26.57 \mathrm{mg} \mathrm{L}^{-1} ; 61.53 \pm 7.57 \mathrm{mg}$ $\mathrm{L}^{-1}$ and $112.68 \pm 19.07 \mathrm{mg} \mathrm{L}^{-1} ; 63.18 \pm 8.57 \mathrm{mg} \mathrm{L}^{-1}$ in August and November, respectively. No significant relationship was found between CI or MY and the environmental parameters.

\section{Meat yield and condition index}

Monthly variations in the MY and CI of $O$. $e d u$ lis are shown in Table 1. These two parameters are positively correlated $(\mathrm{P}<0.01)$ and the lowest values 

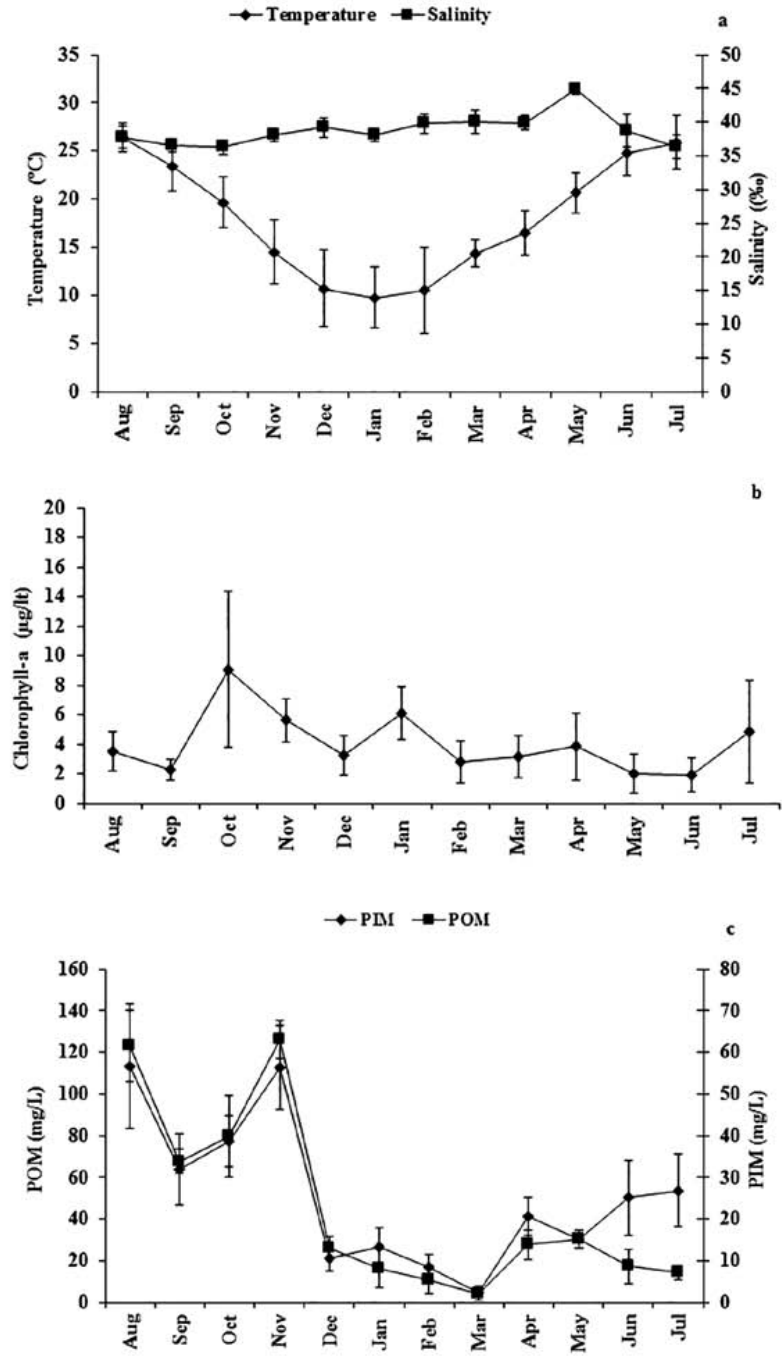

Fig. 2. - Mean monthly variation of seawater temperature (a), salinity (b), chlorophyll $a$ (b), particulate inorganic matter (PIM) (c) and particulate organic matter (POM) (c) in Homa Lagoon from August 2008 to July 2009.

were observed in December and February. After this month, the MY and the CI increased until April, when the highest values were recorded: $20.42 \pm 3.42 \%$ and $12.29 \pm 1.45$, respectively (Table 1 ). CI and MY were not correlated with any of the environmental parameters. During the experimental period, the oyster quality changed from fine to "spéciale".

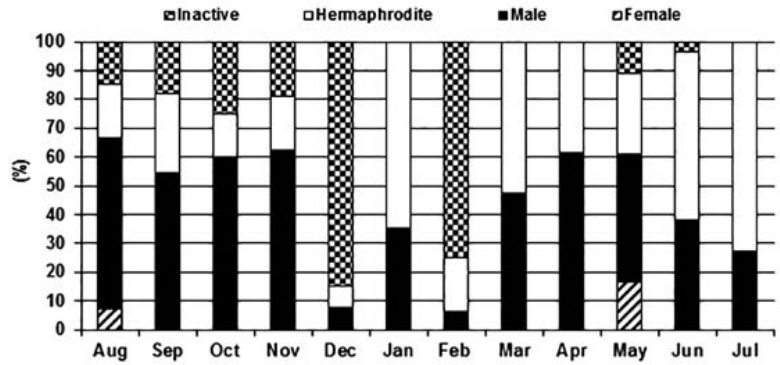

Fig. 3. - Monthly variations in the sex ratio of Ostrea edulis from August 2008 to July 2009.

\section{Biochemical analysis}

Monthly variations in the protein, total lipid and glycogen content are shown in Table 1. Protein content varied during the study period, with the minimum value being determined in July $(37.97 \pm 1.06 \%)$ and the maximum value in February $(50.56 \pm 1.11 \%)$. This parameter was negatively correlated with CI and GI $(\mathrm{P}<0.05)$. Total lipids and $\mathrm{CI}$ decreased until December, when the value was $3.34 \pm 0.67 \%$, the lowest value of the year. Then the total lipid value increased significantly in January, when oysters had the highest proportion of individuals in the ripe and partly spawning stages. This parameter was correlated positively with CI, GI and seawater temperature and inversely with salinity $(\mathrm{P}<0.05)$. However, the total lipid value sharply decreased one month later. At the same time, CI showed the lowest value of the year in February. These dramatic fluctuations changed in April and reached a constant rate until the end of the study (July). Glycogen value peaked in October at 29.39 $2.19 \%$, but decreased drastically after this month and reached a minimum value in February. No correlations were observed between glycogen values and other parameters $(\mathrm{P}>0.05)$.

\section{Histology}

A total of 360 individuals were studied, with mean proportions of $2.2 \%$ female, $42.6 \%$ male, $37 \%$ hermaphrodite and $17.9 \%$ inactive (Fig. 3). However, the sex ratio varied significantly during the study period $(\mathrm{P}<0.05)$. Female individuals were observed only in August and May, whereas males were dominant throughout the study period and hermaphrodites were

Table 1. - Monthly variation (mean \pm SD) meat yield, condition index, protein, total lipids, and glycogen in Ostrea edulis from August 2008

\begin{tabular}{|c|c|c|c|c|c|}
\hline Month & Meat yield (\%) & Condition index & Protein $(\%)$ & Total lipids (\%) & Glycogen (\%) \\
\hline August & $8.28 \pm 1.42$ & $6.35 \pm 1.01$ & $43.38 \pm 1.89$ & $6.27 \pm 0.97$ & $17.08 \pm 2.21$ \\
\hline September & $6.93 \pm 1.12$ & $4.73 \pm 0.79$ & $46.37 \pm 1.25$ & $5.15 \pm 0.82$ & $16.15 \pm 1.75$ \\
\hline October & $8.37 \pm 2.52$ & $5.23 \pm 1.14$ & $44.07 \pm 2.41$ & $5.60 . \pm 0.92$ & $29.39 \pm 2.19$ \\
\hline November & $9.63 \pm 2.85$ & $8.72 \pm 1.12$ & $45.77 \pm 1.12$ & $5.10 \pm 0.94$ & $6.30 \pm 1.27$ \\
\hline December & $5.8 \pm 1.72$ & $3.84 \pm 0.77$ & $50.35 \pm 2.12$ & $3.34 \pm 0.67$ & $12.65 \pm 2.25$ \\
\hline January & $14.74 \pm 1.68$ & $7.88 \pm 1.24$ & $44.49 \pm 0.56$ & $5.58 \pm 1.11$ & $6.97 \pm 1.75$ \\
\hline February & $5.21 \pm 0.65$ & $2.69 \pm 0.91$ & $50.56 \pm 1.11$ & $4.39 \pm 0.82$ & $2.26 \pm 0.25$ \\
\hline March & $13.17 \pm 2.1$ & $7.75 \pm 1.53$ & $38.97 \pm 1.32$ & $4.69 \pm 1.45$ & $3.75 \pm 1.07$ \\
\hline April & $20.42 \pm 3.42$ & $12.29 \pm 1.45$ & $42.39 \pm 1.14$ & $6.15 \pm 1.01$ & $13.21 \pm 2.1$ \\
\hline May & $9.96 \pm 1.14$ & $6.39 \pm 0.88$ & $43.91 \pm 0.89$ & $6.52 \pm 1.25$ & $18.80 \pm 1.33$ \\
\hline June & $10.15 \pm 2.2$ & $9.62 \pm 1.76$ & $47.50 \pm 2.82$ & $6.13 \pm 0.88$ & $25.39 \pm 2.99$ \\
\hline July & $7.97 \pm 1.12$ & $10.16 \pm 1.3$ & $37.97 \pm 1.06$ & $6.14 \pm 1.12$ & $28.26 \pm 1.71$ \\
\hline
\end{tabular}




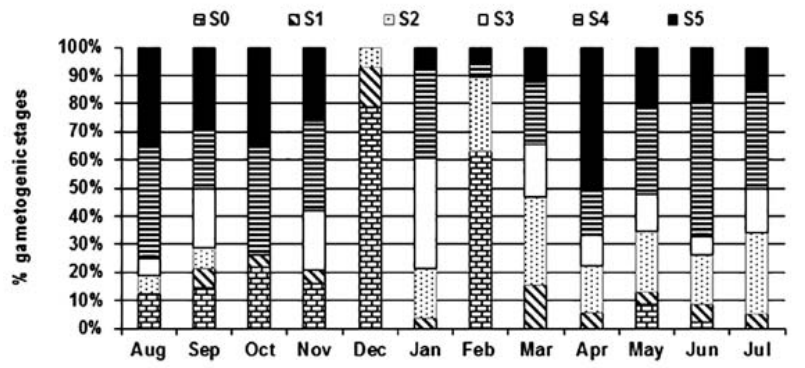

Fig. 4. - Percentage of different stages in total population of Ostrea edulis from August 2008 to July 2009 (inactive (S0), early developing (S1), developing (S2), ripe (S3), partly spawned (S4) and fully spawned (S5))
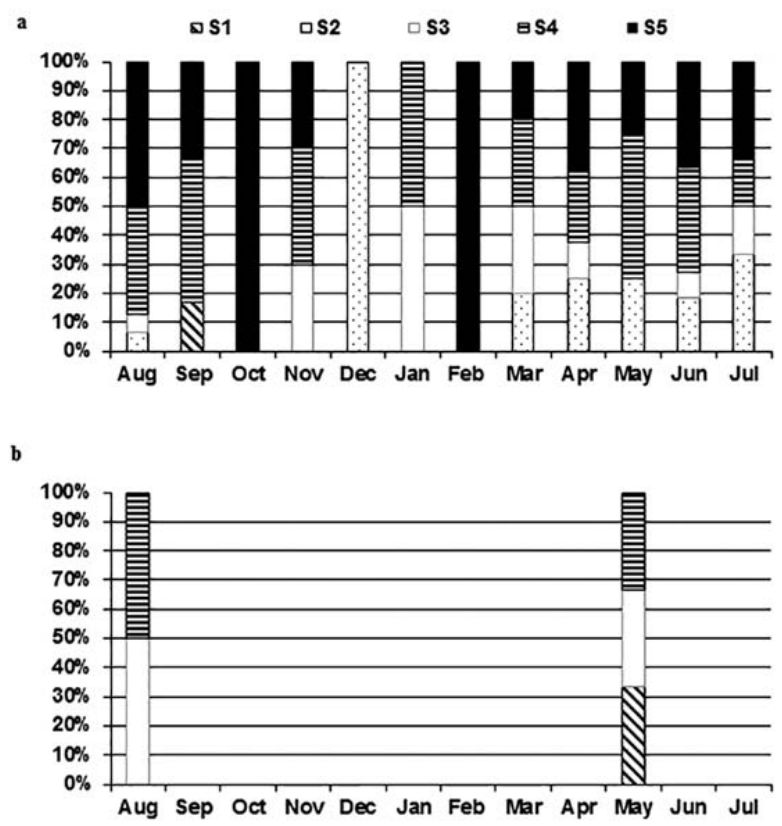

Fig. 5. - Percentage of different stages in male (a) and female (b) of Ostrea edulis from August to July (early developing (S1), developing (S2), ripe (S3), partly spawned (S4) and fully spawned (S5)).

observed in each month. The highest percentage of individuals in the inactive stage was recorded in December and February, but inactive individuals were not observed in January March, April and July. The annual reproductive cycle of the flat oyster is summarized in Figure 4. The gonad development showed that gametogenesis occurred throughout the year. The highest percentage of individuals in the inactive stage occurred in December. The early developing stage for males was $16 \%$ in September. Partly spawning males were observed throughout the experimental period, except in October, December and February, and maximum values were observed in September and January (Fig. 5). Developing and fully spawning females were not observed during the study. In August, half of the population was in the ripe stage and the other half was in the partial spawning stage. A comparison of different sex categories indicated that, in general, the population was $46 \%$ female-dominant hermaphrodites. Ambisexual and predominantly male individuals had the same proportion (Fig. 6). Predominantly female individuals were found throughout the

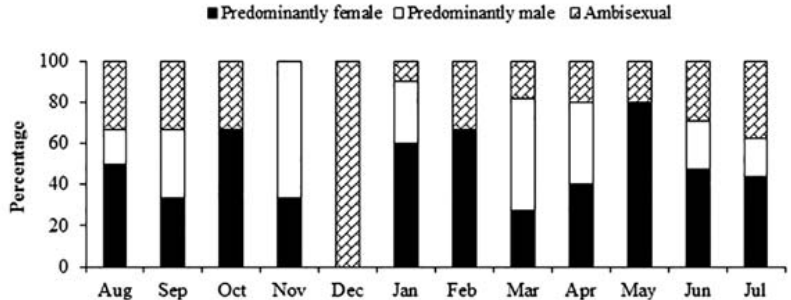

Fig. 6. - Monthly variations in predominantly female, predominantly male and ambisexual in hermaphrodite individuals from August 2008 to July 2009.

study period (except in December), with a maximum percentage $(80 \%)$ in May. The highest percentage of the ambisexual phase was observed as $100 \%$ in December. In this month, all hermaphroditic individuals were ambisexual. The highest percentage of males in the ripe stage and partly spawning hermaphrodite individuals was observed in January (45\%) and October (100\%), respectively (Fig. 7). In February, female hermaphrodite individuals were all in the developing stage (100\%). In August, most gonads (80\%) were in the partly spawned stage and some (20\%) were in the fully spawned stage. Spawning was observed throughout the year, except in September, December and February. Female hermaphrodite gonad development began in October and reached the maximum percentage in February. The ripe stage was detected in the short term and the greatest percentage was seen in September. Spawning was observed in either male or female individuals almost all of the year. The highest percentages of the spawning stage were observed in August and September. The GI varied between 1.2
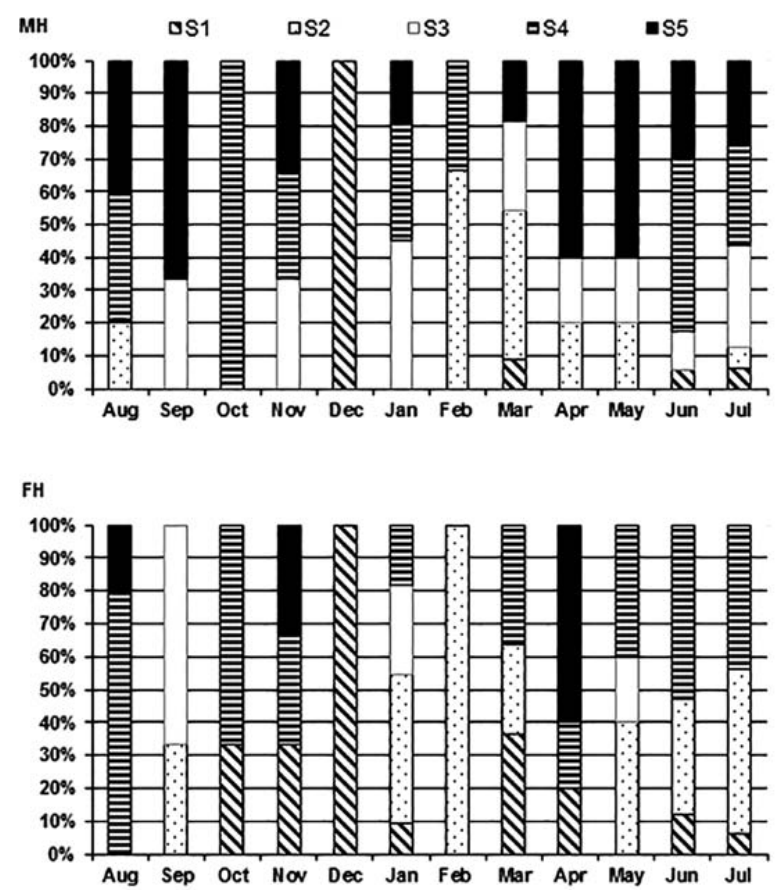

Fig. 7. - Percentage of different stages in male hermaphrodite $(\mathrm{MH})$ and female hermaphrodite $(\mathrm{FH})$ of Ostrea edulis from August to July (early developing (S1), developing (S2), ripe (S3), partly spawned (S4) and fully spawned (S5)). 
Table 2. - Matrix of Pearson correlation of temperature (T), salinity (S), particulate inorganic matter (PIM), particulate organic matter (POM), chlorophyll $a(\mathrm{CHL})$, meat yield (MY), condition index (CI), gonad index (GI), protein (P), total lipids (L) and glycogen (G). * Correlation is significant at the 0.05 level (two-tailed); ** Correlation is significant at the 0.01 level (two-tailed).

\begin{tabular}{|c|c|c|c|c|c|c|c|c|c|c|c|}
\hline & $\mathrm{T}$ & S & PIM & POM & CHL & MY & CI & GI & $\mathrm{P}$ & $\mathrm{L}$ & G \\
\hline $\mathrm{T}$ & 1 & -0.073 & 0.511 & 0.301 & -0.163 & -0.163 & 0.270 & 0.327 & -0.388 & $0.685^{*}$ & 0.575 \\
\hline$S$ & & 1 & 0.056 & 0.073 & 0.060 & -0.446 & -0.166 & -0.476 & 0.187 & $-0.641 *$ & 0.166 \\
\hline PIM & & & 1 & $0.934 * *$ & 0.342 & -0.173 & 0.132 & 0.117 & -0.062 & 0.373 & 0.383 \\
\hline POM & & & & 1 & 0.325 & -0.214 & -0.095 & -0.046 & 0.062 & 0.163 & 0.298 \\
\hline CHL & & & & & 1 & 0.097 & 0.064 & 0.119 & -0.226 & 0.066 & 0.397 \\
\hline MY & & & & & & 1 & $0.757 * *$ & 0.392 & -0.458 & 0.392 & -0.147 \\
\hline $\mathrm{CI}$ & & & & & & & 1 & 0.567 & $-0.614^{*}$ & $0.585^{*}$ & -0.022 \\
\hline GI & & & & & & & & 1 & $-0.612 *$ & $0.606 *$ & -0.122 \\
\hline $\mathrm{P}$ & & & & & & & & & 1 & -0.530 & -0.130 \\
\hline $\mathrm{L}$ & & & & & & & & & & 1 & 0.345 \\
\hline G & & & & & & & & & & & 1 \\
\hline
\end{tabular}

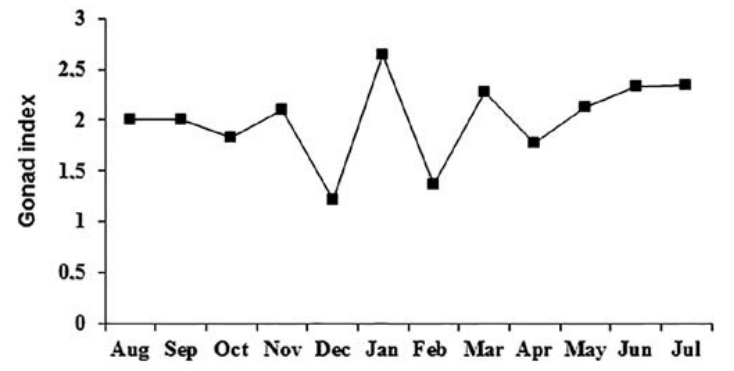

Fig. 8. - Variation of gonad index (GI) in Ostrea edulis from August 2008 to July 2009.

and 2.6 (Fig. 8). The highest values were found in November (2.1), January (2.64) and March (2.28), as a result of a higher number of mature and partly spawning individuals; male and hermaphrodite male individuals were dominant. Minimal values were determined in December and February, when most of the individuals were at the inactive stage. The GI was positively correlated with total lipid value and inversely correlated with protein content, but not with glycogen $(\mathrm{P}<0.05)$ (Table 2$)$.

\section{DISCUSSION}

The CI, a measure of apparent health and commercial quality of bivalves (Orban et al. 2002), is a parameter of ecophysiological and economic importance, especially with regard to industrial processing. According to Okumus et al. (1998), fluctuations in the $\mathrm{CI}$ and MY have important implications for cultivation and harvesting strategy. Meat quality and biochemical composition in bivalves primarily depends on food, environmental parameters (mainly temperature) (Brown and Hartwick 1988, Austin et al. 1993, Fabioux et al. 2005) and reproductive activities (Chávez-Villalba et al. 2007). In this study, MY and CI ranged from $2.69 \%$ to $12.29 \%$ and from $5.21 \%$ to $20.42 \%$, respectively. Meat yield and CI of O. edulis in the present study was similar to the values reported for the same species by Acarli et al. (2011) and Yildiz et al. (2011) in Turkey and by Pogoda et al. (2011) in Germany. Based on the AFNOR index for MY values recorded in this study, the oysters could be ranked as "spéciale" according to the classifications given by Soletchnik et al. (2001). In this study, higher values than those of Crassostrea gi- gas in Tunisia (Dridi et al. 2007), in France (Soletchnik et al. 2001) and in Germany (Pogoda et al. 2011) were found, showing that this population has good quality for consumption nearly throughout the year.

The gametogenic cycle of bivalve species is affected by endogenous rhythms such as energy reserves, hormonal cycles and genotype (Gaspar et al. 1999, Lucas and Southgate 2003), and y exogenous factors such as food availability, temperature, photoperiod and salinity (Kennedy 1983, Newell et al. 1982, Jeffs et al. 2002). Temperature is an important environmental parameter in the regulation of gametogenesis in oysters (Chávez-Villalba et al. 2002, Helm et al. 2004, da Silva et al. 2009), but the onset of gametogenesis in O. edulis occurs at different temperatures and depends on location (Shpigel 1989). In our study, gonad development was constant throughout the year, except for a decrease in December and February, when the temperature was recorded as $10^{\circ} \mathrm{C}$. However, the highest value of the GI was recorded during low temperatures (February $9^{\circ} \mathrm{C}$ ). This situation can be explained by the fact that most of the individuals in the population were males, which were faster than females to complete the reproductive process. Indeed, the water temperature in the Homa Lagoon did not limit the reproduction of the flat oyster. The same results have been reported by Shpigel (1989) for the Gulf of Eilat (Israel), Ruiz (1992) for Galicia (Spain), Cano et al. (1997) for Mar Menor (Spain) and Carlucci et al. (2010) for the Taranto Sea (Italy).

Besides temperature, food availability is also affecting broodstock energy reserves and gametogenesis in bivalves (Baghurst and Mitchell 2002, Frias and Segovia 2009, Fourniera et al. 2012). In this investigation, chlorophyll $a$ and organic matter amounts were recorded as very high in the Homa Lagoon and levels are probably sufficient for the onset of gametogenesis and gonad development throughout the year. Food amounts in the study area are continuously enhanced due to the input of nutrition from the open sea. The improved nutrient availability in the lagoon can be attributed to the inflow from the sea water environment, as well as the shallow lagoon bed which leads to an increase in chlorophyll $a$ as a plankton biomass indicator. Chlorophyll $a$ and organic matter levels showed no correlation with gametogenesis because food quality was always high. Nevertheless, the GI can be associated with chlorophyll $a$ from winter to early spring; both fluctuate at the same time. 
Ostrea edulis is a rhythmical consecutive hermaphrodite species, in which both sexes occur in the same section of a gonad. Oysters alternate between male and female sexual phases and function as males in the early spawning season (Orton 1927). Environmental conditions such as temperature, salinity and food availability also affect the sex ratio of O. edulis (Diaz-Almela 2004, González-Araya et al. 2013). High temperature and salinity, especially, lead to the increase of the male proportion, while low temperature and salinity are associated with an increased proportion of females (Rao 1956). Quayle (1969) reported that if the food supply of $C$. gigas is poor, there is a tendency for females to change into males. This situation is explained by Diaz-Almela (2004) using the fact that there is probably a heavier energy cost in the development of ovocytes, and thus a lower probability of becoming female. In this study, we found that the ratio of male-to-female and male-to-hermaphrodite oysters was more than 19:1 and 1.15:1, respectively. According to Yolkolu and Lök (2000), and Eversole (1989), a high ratio of casual hermaphroditism and maleness may be the result of physiological stress, such as sudden changes in temperature and salinity or high turbidity. Water temperature of the Homa Lagoon differed greatly between day and night time, especially in the winter season. Moreover, one gametogenic phase follows the next without undergoing complete reabsorption. The annual sex ratio in marine bivalves is nearest to 1:1 in a healthy population (Morton 1991). In this study, the female percentage was low in the Homa Lagoon, but the percentage of female hermaphrodite individuals were high. We think that this situation is quite important in terms of balancing and future sustainability of the population. Consequently, female hermaphrodite individuals are supporting the oyster population.

The main energy reserves for gametogenesis in bivalves are lipid and glycogen contents (Kang et al. 2000, Dridi et al. 2007, Pogoda et al. 2013). The reserve of energy can vary according to bivalve species (Lodeiros et al. 2001, Delgado and Pérez Camacho 2003, ViteGaría and Saucedo 2008). Bayne (1976) states that the stored energy of bivalves used for gametogenesis can be classified into two categories: conservative species that use the energy stored in various organs (adductor muscle, digestive gland and mantle) and opportunistic species that use the energy from recently ingested food. Additionally, Joaquim et al. (2008) stated that some of the bivalve species use both methods. The strategy used to provide the energy required for gametogenesis can differ even in oysters of the same species (Li et al. 2006). Being an opportunistic or a conservative species is closely related to the quality and quantity of food. Our results showed that there is no resting period for this species and glycogen was not accumulated during the study period. Kang et al. (2000) found similar results and noted that because oysters have only a very short gonadal resting stage, the relationship between gonadal development and each biochemical component used to maintain energy and for reproduction is difficult to assess. The behaviour of $O$. edulis was opportunistic because there was sufficient food in Homa Lagoon throughout the year.
According to Dridi et al. (2007), lipid variations are closely related to gamete development, with the highest levels of lipids in the periods of maximum ripeness (Dridi et al. 2007) and the lowest in the periods of spawning (Liu et al. 2008). Similarly, our results showed a positive relationship between lipid and GI. The minimum total lipid value was determined in December and February, during the spawning period and the resting period. On the other hand, total lipid increased in January when the gonad was mature.

Recently, many authors have reported that variations in protein seem to be heavily influenced by the reproductive cycle and it is likely that the protein accumulated in the tissues at earlier stages of maturation is used for the oocyte development and growth (Berthelin et al. 2000, Marin et al. 2003). However, Mladineo et al. (2007) reported that the use of stored protein as an energy source is widely dependant on the availability of the other sources such as carbohydrates and lipids, being lower when these other sources are used at higher levels, and vice versa. According to Whyte et al. (1990), protein was more efficient than carbohydrate as the main contributor of energy in lean times and fed the oysters during the winter months, when food was scarce. In the present study, protein was the major organic content found in oysters and the decline in protein coincided with maturation.

\section{ACKNOWLEDGEMENTS}

This study was supported by BAP Project (SUF/014)/Ege University and was conducted in Homa (Sufa) Lagoon, Fishery Faculty of Ege University. Special thanks to Sedat Tepeli, and Bayram Ceylan for their help with technical assistance during the study period. Sincere thanks are also due to two anonymous referees, whose suggestions greatly improved the manuscript.

\section{REFERENCES}

Acarli S., Lok A., Kücükdermenci A., et al. 2011. Comparative growth, survival and condition index of flat oyster, Ostrea edulis (Linnaeus 1758) in Mersin Bay, Aegean Sea, Turkey. Kafkas Univ. Vet. Fak. Derg. 17 (2): 203-210.

Abad M., Ruiz C., Martinez D., et al. 1995. Seasonal variation of lipid classes and fatty acids in flat oyster, Ostrea edulis, from San Cibran (Galicia, Spain). Comp. Biochem. Physiol. 110: $109-118$. http://dx.doi.org/10.1016/0742-8413(95)00006-a

Austin H., Haven D.S., Moustafa M.S. 1993. The relationship between trends in a condition index of the American oyster, Crassostera virginica and environmental parameters in three Virginia Estuaries. Estuaries 16: 362-374. http://dx.doi.org/10.2307/1352508

Baghurst B., Mitchell J. 2002. Sex-specific growth and condition of the Pacific oyster (Crassostrea gigas Thunberg). Aquac. Res. 33: $1253-1263$. http://dx.doi.org/10.1046/j.1365-2109.2002.00788.x

Bayne B.L. 1976. Aspects of reproduction in bivalve molluscs. In: Wiley M.L. (ed). Estuarine Processes. Academic Press, New York. pp. 432-448. http://dx.doi.org/10.1016/b978-0-12-751801-5.50043-5

Berthelin C., Kellner K., Mathieu M. 2000. Storage metabolism in the Pacific oyster (Crassostrea gigas) in relation to summer mortalities and reproductive cycle (West of Coast of France). Comp. Biochem. Physiol. 125: 359-369. http://dx.doi.org/10.1016/S0305-0491(99)00187-X 
Bligh E., Graham W., Dyer J. 1959. A rapid method of total lipid extraction and purification. Can. J. Biochem. Physiol. 37(8): 911-917. http://dx.doi.org/10.1139/059-099

Brown J.R, Hartwick E.B. 1988. Influence of temperature, salinity and available food upon suspended culture of the Pacific oyster, Crassostrea gigas: II. Condition index and survival. Aquaculture 70(3): 253-267 http://dx.doi.org/10.1016/0044-8486(88)90100-7

Cano J., Rosique M.J., Rocamoro J. 1997. Influence of environmental parameters on reproduction of the European flat oyster (Ostrea edulis L.) in a Coastal Lagoon (Mar Menor, Southern Spain). J. Molluscan Stud. 63: 187-196. http://dx.doi.org/10.1093/mollus/63.2.187

Carlucci R., Sasanelli A., Matarrese A., et al. 2010. Experimental data on growth, mortality and reproduction of Ostrea edulis (L., 1758) in a semi-enclosed basin of the Mediterranean Sea. Aquaculture 306: 167-176. http://dx.doi.org/10.1016/j.aquaculture.2010.05.026

Chávez-Villalba J., Barret J., Mingant C., et al. 2002. Autumn conditioning of the oyster Crassostrea gigas: a new approach. Aquaculture 210: 171-186. http://dx.doi.org/10.1016/S0044-8486(02)00059-5

Chávez-Villalba J., Barret J., Mingant C., et al. 2003. Influence of timing of broodstock collection on conditioning, oocyte production, and larval rearing of the oyster, Crassostrea gigas (Thunberg), at six production sites in France. J. Shellfish Res. 22 (2): 465-474.

Chávez-Villalba J., Villelas-Ávila R., Cáceres-Martínez C. 2007. Reproduction, condition and mortality of the Pacific oyster Crassostrea gigas (Thunberg) in Sonora, México. Aquac. Res. 38: $268-278$. http://dx.doi.org/10.1111/j.1365-2109.2007.01662.x

Crosby M.P., Gale L.D. 1990. A review and evaluation of bivalve condition index methodologies with a suggested standard method. J. Shellfish Res. 9: 233-237.

Çelik M.Y., Karayücel S., Karayücel I., et al. 2015. The effects of environmental factors on survival, growth and biochemical composition of transplanted oysters (Ostrea edulis Linnaeus, 1758) from Aegean Sea to southern Black Sea. Aquac. Res. 46: 959-968. http://dx.doi.org/10.1111/are.12253

da Silva P.M., Fuentes J., Villalba A. 2009. Differences in gametogenic cycle among strains of the European flat oyster Ostrea edulis and relationship between gametogenesis and bonamiosis. Aquaculture 287: 253-265. http://dx.doi.org/10.1016/j.aquaculture.2008.10.055

Delgado M., Pérez Camacho A. 2003. A study of gonadal development in Ruditapes decussatus (L.) (Mollusca, Bivalvia) using image analysis techniques: influence of food ration and energy balance. J. Shellfish Res. 22(2): 435-441.

Diaz-Almela E., Boudry P., Launey S., et al. 2004. Reduced Female Gene Flow in the European flat oyster Ostrea edulis. J. Heredity 95(6): 510-516. http://dx.doi.org/10.1093/jhered/esh073

Doğan A., Cinar M.E., Önen M., et al. 2005. Seasonal analysis of soft bottom zoobenthic communities in polluted and unpolluted areas of Izmir Bay (Aegean Sea). Senckenbergiana Maritima 35: $133-145$. http://dx.doi.org/10.1007/BF03043182

Dridi S., Romdhane M.S., Elcafsi M. 2007. Seasonal variation in weight and biochemical composition of the Pacific oyster, Crassostera gigas in relation to gametogenic cycle and environmental conditions of the Bizert logoon, Tunisia. Aquaculture 263: 238-248. http://dx.doi.org/10.1016/j.aquaculture.2006.10.028

Dubois M., Gilles K.A., Hamilton J.K., et al. 1956. Colorimetric method for determination of sugars and related substances. Anal. Chem. 28: 350-356. http://dx.doi.org/10.1021/ac60111a017

EFSA (European Food Safety Authority). 2010. Scientific Opinion on the increased mortality events in Pacific oysters, Crassostrea gigas. EFSA J. 8(11):1-60.

Eversole A.G. 1989. Gametogenesis and spawning in North American clam populations: implications for culture. In: Manzi J.J. and Castagna M. (eds) Clam mariculture in North America. Elsevier Science. Amsterdam, pp.75-109.

Fabioux C., Huvet A., Le Souchu P., et al. 2005. Temperature and photoperiod drive Crassostrea gigas reproductive internal clock. Aquaculture 250: 458-470. http://dx.doi.org/10.1016/j.aquaculture.2005.02.038

FAO. 2012. Fisheries Statistics, Aquaculture Production 2002. Rome 98(2). 209 pp.

Fischer W., Bauchot M.-L., Schneider M. 1987. Mèditerranèe et mer Noire, Zone de pêche 37. Révision 1, Volume 1 Végétaux et Invertébrés, Rome, $631 \mathrm{pp}$.

Fourniera J., Levesque E., Pouvreau S., et al. 2012. Influence of plankton concentration on gametogenesis and spawning of the black lip pearl oyster Pinctada margaritifera in Ahe atoll lagoon (Tuamotu archipelago, French polynesia). Mar. Pollut. Bull. 65(10-12): 463-470. http://dx.doi.org/10.1016/j.marpolbul.2012.03.027

Frias R., Segovia M. 2009. Gonad development of the Japanese oyster Crassostrea gigas in a recirculating system: first step toward the development of conditioning and maturation protocols. J. Shellfish Res. 29(2): 303-308. http://dx.doi.org/10.2983/035.029.0204

Gaspar M.B., Ferreira R., Monteiro C.C. 1999. Growth and reproductive cycle of Donax trunculus L., (Mollusca: Bivalvia) off Faro, southern Portugal. Fish. Res. 41: 309-316. http://dx.doi.org/10.1016/S0165-7836(99)00017-X

González-Araya R., Quillien V., Robert R. 2013. The effects of eight single microalgal diets on sex-ratio and gonad development throughout European flat oyster (Ostrea edulis L.) conditioning. Aquaculture 400-401: 1-5. http://dx.doi.org/10.1016/j.aquaculture.2013.02.036

Helm M.M., Bourne N., Lovatelli A. 2004. Hatchery Culture of Bivalves. A practical Manual: Fisheries Technical Paper, NO. 471 FAO Roma 200 pp.

Kang C.K., Park S.M., Lee P.Y., et al. 2000. Seasonal variations in condition, reproductive activity, and biochemical composition of the Pacific oyster, Crassostrea gigas (Thunberg) in suspended culture in two coastal bays Korea. J. Shellfish Res. 19(2): 771-778

Kennedy V.S. 1983. Sex rations in oysters emphasizing Crassostrea virginica from Chesapeake Bay, Maryland. The Veliger 25(4): 329-337.

Kumlu M., Lok A. 2007. Crustacean and Shellfish Production. In: Karataş S., Küçüktaș H., Okumuș I. (eds). Marine Aquaculture in Turkey. Istanbul Turkey. pp.71-80.

Jeffs A.G., Dunphy B.J., Wells R.M. 2002. Experimental effects water temperature on the gametogenic development of broodstock in the oyster, Ostrea chilensis. J. Shellfish Res. 21(2): 743-747.

Joaquim S., Matias D., Lopes B., et al. 2008. The reproductive cycle of white clam Spisula solida (L.) (Mollusca: Bivalvia): Implications for aquaculture and wild stock management. Aquaculture 281:43-48. http://dx.doi.org/10.1016/j.aquaculture.2008.05.018

Li Q., Liu W., Shirasu K., et al. 2006. Reproductive cycle and biochemical composition of the Zhe oyster Crasssotrea plicatula Gmelin in an eastern coastal bay of China. Aquaculture 261: 752-759.

http://dx.doi.org/10.1016/j.aquaculture.2006.08.023

Liu W., Li Q., Yuan Y., et al. 2008. Seasonal variation in reproductive activity and biochemical composition of the cockle Fulvia mutica (Reeve) from the eastern coast of China. J. Shellfish Res. 27(2): 405-411.

http://dx.doi.org/10.2983/0730-8000(2008)27[405:SVIRAA]2 $0 . \mathrm{CO} ; 2$

Lodeiros C.J., Rengel J.J., Guderley H.E., et al. 2001. Biochemical composition and energy allocation in the tropical scallop $L y$ ropecten (Nodipecten) nodosus during the months leading up to and following the development of gonads. Aquaculture 199: 63-72.

http://dx.doi.org/10.1016/S0044-8486(01)00505-1

Lok A., Acarli S. 2006. Preliminary settlement studies of flat oyster (Ostrea edulis, L.) on oyster and mussel shell collectors in Karantina Island (Turkey). Israel J. Aquac. 58(2): 105-115.

Lowry O., Roseborough N.I., Farrand A.L., et al. 1951. Protein measurement with the phenol reagant. J. Biol. Chem. 193: 263-275.

Lucas J.S., Southgate P.C. 2003. Aquaculture: farming aquatic animals and plants. UK. Fishing News Books, a Blackwell Publishing Company. 502 pp.

Marin M.G., Moschino V., Deppierşi L., et al. 2003. Variation in gross biochemical composition, energy value and condition index of $T$. philippinarum from the Lagoon of Venice. Aquaculture 219: 859-871. http://dx.doi.org/10.1016/S0044-8486(03)00035-8 
Matias D., Joaquim S., Matias A.M., et al. 2013. The reproductive cycle of the European clam Ruditapes decussatus (L., 1758) in two Portuguese populations: Implication for management and aquaculture programs. Aquaculture 406-407: 52-61. http://dx.doi.org/10.1016/j.aquaculture.2013.04.030

Mladineo I., Pherda M., Orhanović S., et al. 2007. The reproductive cycle, condition index and biochemical composition of the horse-bearded mussel Modious barbatus. Helgol. Mar. Res. 61: 183-192. http://dx.doi.org/10.1007/s10152-007-0065-8

Morton B. 1991. Do the Bivalvia demonstrate environment-specific sexual strategies? A Hong Kong model. J. Zool. Lond. 223: 131-142. http://dx.doi.org/10.1111/j.1469-7998.1991.tb04754.x

Newell R.I.E., Hilbish T.J., Koehn R.K., et al. 1982. Temporal variation in the reproductive cycle of Mytilus edulis L. (Bivalvia, Mytilidae) from localities on the East Coast of the United States. Biol. Bull. 162: 299-310. http://dx.doi.org/10.2307/1540985

Okumus I., Hadrian P., Stirling H.P. 1998. Seasonal variations in the meat weight, condition index and biochemical composition of mussels (Mytilus edulis L.) in suspended culture in two Scottish sea lochs. Aquaculture 159(3-4): 249-261. http://dx.doi.org/10.1016/S0044-8486(97)00206-8

Orban E., Di Lena G., Nevigato Casini I., et al. 2002. Seasonal changes in meat content, condition index and chemical composition of mussel (Mytilus galloprovincialis) cultured in two different Italian sites. Food Chem. 77: 57-65. http://dx.doi.org/10.1016/S0308-8146(01)00322-3

Orton J.H. 1927. Observations and experiments on sex-change in the European oyster (O. edulis). J. Mar. Biol. Assoc. 14: 967-1045 http://dx.doi.org/10.1017/S0025315400051183

Pogoda B., Buck B.H., Hagen W. 2011. Growth performance and condition of oysters (Ostrea edulis and Crassostrea gigas) farmed in an offshore environment (North Sea, Germany. Aquaculture 319: 484-492. http://dx.doi.org/10.1016/j.aquaculture.2011.07.017

Pogoda B., Buck B.H., Saborowski R., et al. 2013. Biochemical composition of the offshore-cultivated oysters Ostrea edulis and Crassostrea gigas. Aquaculture 400-401: 53-60. http://dx.doi.org/10.1016/j.aquaculture.2013.02.031

Quayle D.B. 1969. Pacific Oyster Culture in British Columbia. Fish. Res. Bd. Can. Bull. 169: 1-192.

Rao K.V. 1956. Seasonal gonadal changes in the adult backwater oyster Ostrea (Crassostrea) madrasensis (Preston), from Ennur near Madras. Proc. Indian Acad. Sci. 44B: 332-356.

Ruiz C., Martinez D., Mosquera G., et al. 1992. Seasonal variations in condition, reproductive activity and biochemical composition of the flat oyster, Ostrea edulis, from San Cibran (Galicia, Spain). Mar. Biol. 112(1): 67-74. http://dx.doi.org/10.1007/BF00349729

Shpigel M. 1989. Gametogenesis of the European flat oyster (Ostrea edulis) and Pacific oyster (Crassostrea gigas) in warm water in Israel. Aquaculture 80: 343-349.

http://dx.doi.org/10.1016/0044-8486(89)90181-6
Siddiqui G., Ahmed M. 2002. Gametogenic patterns of the larviparous oyster Ostrea nomades from Karachi, Pakistan (northern Arabian Sea). Aquac. Res. 33: 1049-1058. http://dx.doi.org/10.1046/j.1365-2109.2002.00769.x

Soletchnik P., Le Moine O., Goulletquer P., et al. 2001. Optimization of the traditional Pacific cupped oyster (Crassostrea gigas Thunberg) culture on the French Atlantic coastline: autumnal fattening semi-closed ponds. Aquaculture 199: 73-91. http://dx.doi.org/10.1016/S0044-8486(01)00554-3

Soria R.G., Pascual M.S., Cartes V.H.F. 2002. Reproductive cycle of the cholga paleta, Atrina seminude Lamarck, 1819 (Bivalvia: Pinniade) from Northern Patagonia, Argentina. J. Shellfish Res. 21(2): 479-488

Strickland J.D.H., Parsons, T.R. 1972. A Practical Handbook of Seawater Analysis. Bull. Fish. Res. Board Canada. 310 pp.

Vite-Garía N., Saucedo P.E. 2008. Energy storage and allocation during reproduction of Pacific winged pearl oyster Pteria sterna at Bahía de La Paz, Baja California Sur, Mexico. J. Shellfish Res. 27(2): 375-383.

http://dx.doi.org/10.2983/0730-8000(2008)27[375:ESAADR]2 $0 . \mathrm{CO} ; 2$

Walne P.R., Mann R. 1975. Growth and biochemical composition in Ostrea edulis and Crassostrea gigas. Proceeding of the 9th European Marine Biology Symposium, Aberdeen Univ. Press pp. 587-607.

Whyte J.N.C., Englar J.R., Carswell B.L. 1990. Biochemical composition and energy reserves in Crassostrea gigas exposed to different levels of nutrition. Aquaculture 90: 157-172. http://dx.doi.org/10.1016/0044-8486(90)90338-N

Wilson C., Scotto L., Scarpa J., et al. 2005. Survey of water quality, oyster reproduction and oyster health status in the St. Luice Estuary. J. Shellfish Res. 24(1): 157-165. http://dx.doi.org/10.2983/0730-8000(2005)24[157:SOWQOR] 2.0.CO;2

Yan H., Li Q., Yu R., et al. 2010. Seasonal variations in biochemical composition and reproductive activity of Venus Clam Cyclina sinensis (Gmelin) from the yellow river delta in Northern China in relation to environmental factors. J. Shellfish Res. 29(1): 91-99. http://dx.doi.org/10.2983/035.029.0132

Y1ldı H., Berber S., Acarlı S., et al. 2011. Seasonal variation in the condition index, meat yield and biochemical composition of the flat oyster Ostrea edulis (Linnaeus, 1758) from the Dardanelles, Turkey. Ital. J. Anim. Sci. 10: 22-26. http://dx.doi.org/10.4081/ijas.2011.e5

Yildız H., Lök A., Acarlı S., et al. 2013. Influence of different collector materials on Mediterranean Mussel, Mytilus gallopravincialis L. 1819 in the Dardanelles. Mar. Sci. Technol. Bull. 2: 20-32.

Yolkolu S., Lök A. 2000. İstiridyelerin (Ostrea edulis Linnaeus, 1758) gonad gelişim safhaları ve cinsiyet oranı. E. Ü. Su Ür. Fak. Der. 17(1-2): 127-136. 